\title{
Dynamic Impact of Trade Openness on the Economic Growth in Nigeria
}

\author{
Sunday Elijah, Ahmed Balarabe Musa.
}

\begin{abstract}
In theory, it was conforming to the accepted standard the open economies grow faster than the closed economies, and respectable economic development level could be achieved. This paper investigates the dynamic impact of trade openness on the economic growth in Nigerian economy between 1980 - 2016 empirically. Secondary data were sourced, from the 2016 Central Bank of Nigeria Statistical Bulletin'. The tests of diagnostic conducted are: cointegration test, unit root test and error correction model. The analysis result revealed the trade openness was found to have negatively impacted on the economic growth in both the short run and long run. Based on study findings, it is recommended that since the imports of the country are more than its export; the government needs to have the present efforts to sustain the diversification of the economy to achieve economic growth led by exports. Furthermore, the collaborative effort of government with private sectors should encourage the export substitute in the nation to discourage importation and promote export of primary commodities especially the ones that have absolute advantages to the nation. Lastly, the study also recommended that the government of the country should sustain the policy of Treasury Single Account (T.S.A) so as that the loopholes will be blocked in the private and public sectors of the nation, and also to make sure there is equity in the utilization of the revenue generated internally for the masses to benefit.
\end{abstract}

Keywords: Trade Openness, ARDL, Import, Export, Economic Growth.

JEL Classification Codes: E30; F10; F14; F19; F49

\section{INTRODUCTION}

Statistics are gathered at the end of each fiscal year for all the economic sectors within every country in the world. These statistics (economic data) shows the individual country's relative rate of economic growth. Besides, the economic growth key driver's debate is ongoing and is inconclusive. Hence, does it matter if the national output of a country falls or rises with time? Majority of developing economies in Sub-Saharan Africa and particularly Nigeria is faced with a growth problem among many challenges; therefore, the answer may be apparent. Economic growth key drivers debate had been going on and still going on (Lewis 1954) (Solow 1956) (Myrdal 1972) (Fields 1980) (Denison and Poullier 1967) (Romer 1986) (Schultz 1980) (Harris and Todaro 1970) (Barro 1991) (Easterly and Levine

Revised Manuscript Received on April 19, 2019.

Sunday Elijah, Department of Economics, Federal University Gusau, Zamfara State, Nigeria and Department of Economics, Faculty of Economics and Management, Universiti Putra Malaysia, 43400 UPM Serdang, Selangor, Malaysia. (Email: elijahsundayecons@gmail.com)

Ahmed Balarabe Musa, Department of General Studies, Nuhu Bamalli Polytechnic, Zaria, Kaduna State, Nigeria. and Department of Economics, Faculty of Economics and Management, Universiti Putra Malaysia, 43400 UPM Serdang, Selangor, Malaysia.
1997) (Barro 2004). These economic growth scenarios observed were also extended to include: economic openness, stable exchange rate, R\&D (Research and Development), FDI (Foreign Direct Investment), foreign aid, surplus labour and improvement in technology and investment in human capital among others.

This paper identified trade openness as one among the economic growth key drivers; this is since according to the World Development Report, even under unfavourable environment, open economies achieved better compared with their closed counterparts. The economic growth rapidly taking place attributed to Asians countries comprising Malaysia, Singapore, Hong Kong, South Korea and Taiwan has been linked to international trade openness. It was conforming with accepted standards that trade openness leads to improvements in large total output, employment generation, resource production, specialisation, income creation and removal or relaxation of foreign exchange limitation (Nnadozie 2013).

However, the economic performance of Nigeria has not been encouraging, because the economic data showed a disparity that is confusing amid the slightly insignificant advancement of welfare for the majority of the populace of Nigeria. The annual economic rate of growth that was averagely over $7 \%$ during the last period also; showed that the economy of Nigeria is one of the economies growing fast in the world economies. The rates of growth were mainly concerted in the agriculture \& trade, suggested that there is a significant benefit of welfare for a lot of Nigerians. Moreover, also agriculture and trade encompass $75 \%$ of the contribution of the non-oil sector; there exists a recorded strong rate of growth in these two sectors. Similarly, it was shown by the World Bank Report 2011 and 2012 that only trade accounted for $11.3 \%$ and $9.6 \%$ respectively (World Bank 2013).

Nevertheless, social welfare improvement indicators were slower than it is expected in perspective of growth. Lastly, poverty reduction and employment generation had not kept the pace the growth of population showing social distress for the number of Nigerians increasing, the youth in particular. Advancement in the direction of the fulfilment of the Sustainable Development Growth slows relatively, and Nigerian economy was ranked one hundred and fifty three out of the one hundred and eighty six countries as at the year 2013, United Nations Human Development Index (World Bank 2013). Besides, Nigerian economy structure has 
remained redundant due to crude oil discovery in the 1970s, not like some of the countries producing oil like Russia, United Arab Emirates and Saudi-Arabia among others. Nigeria was able to diversify its potentials of export-based such that, oil sector continued to be a sector that is dominant in all export virtually and also contribute over $70 \%$ of its foreign earning total.

Currently, in an attempt to meet with the requirements, and at the same time the countries taking part in moving globalization trend and trade openness in international economic systems. Nigeria also is member and signatory of lot of regional \& international agreement, which include: World Trade Organisation, ECOWAS (Economic Community of West Afrian States), IMF (International Monetary Fund), the World Bank \& others. The overriding objectives of the economic partnership in international trade has been the creation of free trade zones by barriers of trade removal, tariffs reduction \& embark on policies of trade that are outward-oriented (Nduka 2013).

Trade openness \& economic growth have been topic of examining in literature field for a couple of time across the nation with use of different sample size, techniques of econometrics and data. Some studies include Sinha (2000), Wacziarg (2001), Elenya (2013), Christopher (2014), Ugbor (2014) and Da'Silva (2014). The studies mentioned above found a statistically significant \& positive relationships between trade openness \& economic growth while studies such as Yanikayya (2003), Kingsley (2014), Ezike, Ogege et al. (2012), and Edoumiekumo, Opukri et al. (2013) found a significant negative relationship between the variables.

In Nigeria a lot of related empirical studies was done on the relationship between trade openness \& Economic growth (Ekpo and Egwaikhide 1994) (Kingsley 2014) (Adejoke 2013) (Alajekwu, Ezeabasili et al. 2013) (Ugbor 2014) (Olaifa, Subair et al. 2013) (Nageri, Ajayi et al. 2013) (Da'Silva 2014) (Ezeuchenne 2017). Accordingly, their findings had varied due to size of sample, different techniques and poor coverage utilised. Hence there is the need of examining empirically. Further, relationship existing between trade openness and economic growth in Nigeria is significant. It is due to this background that this paper examines empirically the dynamic impacts of trade openness on the economic growth in Nigerian economy from $1986-$ 2016. The availability of data formed the choice of period.

\section{LITERATURE REVIEW}

There had been different results on the impact of trade openness on the economic growth.

Saaed (2015), empirically examined causal link between the trade openness, financial development and the economic growth of Kuwait for the spanning period between 1977 2012. They used Granger causality and cointegration tests as techniques of econometrics. Variables they used were: GDP (Gross Domestic Product), TO (Trade Openness) and FD (Financial Development). The study findings revealed statistically significant and positive impact existed between economic growth with the variables. They recommended the need to reform the financial system of Kuwait. Thus, that Kuwait should, therefore, promote its policies of trade openness to enhance both the growths of the GDP and the Financial Sector Development.
Asghar, Hussain et al. (2014) also examined empirically link among the financial sector development, openness and the economic growth in the developing economies for periods, between the year 1978 - 2012. They employed test of panel unit root, test of panel cointegration, test of panel causality and ADF as techniques of analysis. The controlled variables in the analysis were; Financial Development (FD), Trade Open (TO), Foreign Direct Investment (FDI), Human Capital (HC), Gross Capital Formation (GCF) and Interest (R). The study findings indicated that there were evidence that were strong of the long run relationship existed between the FD and the economic growth and bi-directional causality existed between FD and FDI. However, trade openness had statistically significant and positive impacts in all countries. Their research recommended the introduction of policies that are effective which can promote trade between developing countries.

Cerava, Gjanii and Maco (2014) investigated relationship that existed between the trade openness and the economic progress of Albania, for period between 1992 - 2012. The study objective was to find out how trade openness and international trade stimulate growth. The proved result showed there existed statistically significant and positive relationships existed between the trade openness and economic growth. They used model of Autoregressive Distributive Lagged as a technique of econometrics. The results, showed that there is a statistically significant and positive relationship existed between the trade openness and economic growth. That a ten per cent increase in the trade openness leads to 1.3 per cent increase in the real GDP of Albania. The research recommended that policy of free trade should be encouraged by the government of Albania in order to boost the economic progress of Albania.

A study by Altee, Adam, Esmaeel and Saled (2014) on impact of financial development and the trade openness on the economic growth of an open economy Sultanate of Oman between the period 1972 - 2012. They used regarding JJ (Johansen and Juselius), VAR framework and the test of Granger causality as their analysis techniques. The work objective was to establish out how financial development can influence economic growth in the Sultanate of Oman during the investigation period. Findings result revealed a statistically significant and positive influence between the economic growth and controlled variables. On other hand, results showed unidirectional causality existing from the trade openness to the economic growth.

Zaren (2013) investigated the relationships that existed between the trade openness on the economic growth of G7 countries; they used annual data for the period between 1970 - 2011. They used the test of Granger non-causality in the heterogeneous panel as an analysis technique. The result showed a bi-directional causality existing between the trade openness and the economic growth. The research recommended the internal trade integration of the G7 countries should used as an improving policy for their economic growth.

Ulasan (2012) examined the relationship that existed 
between the trade openness and long-run economic growth between the periods 1960 to 2000 . The researcher employed different measures of openness (like ratios of export plus import) instead of the dependence on variables that are proxy. The result showed that different openness variables are statistically significant and positive with long run economic growth.

A research conducted by Ezeuchenne (2017) on impacts of international trade in Nigeria's economic grpwth for the period between 1985 to 2015. The analysis-controlled variables are; interest rate, the balance of trade, export and trade openness. Test of Unit root, test of Johansen cointegration and models of vector error correction were used as analysis techniques. Analysis result proved there is an insignificant relationship in log run between the imports and openness of economy; while a unidirectional relationship existed between economic growth and the trade openness. They recommended that the government should intensify effort in order to boost exports of finished products and also to reduce foreign goods importation. between the economic openness and productivity growth of Nigeria for the periods between 1970 - 2010. Variables selected are; real Gross Domestic Product, openness, real interest rate, exchange rate and unemployment. The researchers used Ordinary Least Square (OLS) in their analysis. The OLS showed that a statistically significant and positive relationship existed between the trade openness and the economic growth. The authors recommended proper utilisation of export revenue, economic diversification and further emphasis the need to encourage the policies of export promotion.

Nageri, Ajayi et al. (2013) analysed empirically impact of trade openness on the economic growth of Nigeria, between the period 1981 to 2009 . Their paper objective was to formulate a policy contribution that is positive which could assist policymakers mapping out the appropriate policies which can determine economic growth sources in Nigeria. The method of OLS regression was used to analyse the multiple econometric models with variables as foreign direct investment, openness, exchange rate and political stability. The study findings indicated that statistically not significant and negative relationship existed between the openness degree and political stability. On other hand, the economic growth and other variables that are used in the research were statistically significant and positive with economic growth. Based on their findings, trade policy recommended the need for reviewing policies of trade especially were recommended. Besides, economic diversification was also recommended mainly in manufacturing, agriculture and power sector privatisation among others.

Olaifa, Subair et al. (2013) tried to establish, whether there are long run relationships between the trade openness and the economic growth of Nigeria, for periods between 1970 - 2010. The research revealed trade openness influences economic in Nigeria. The research adopted Ordinary Least Square (OLS) in the testing influence that exists between the two variables. The research revealed trade openness influence economic growth of Nigeria. The study concluded that conducive atmosphere that can enhance further growth such as the institutional structures
Da'Silva (2014) in their research examine the nexus

reforming as well as better adherence to the international best practices should be encouraged.

Ugbor (2014) researched the causal relationship existing between trade opennes and the economic growth of Nigeria.They divided their analysis into two: the pre and the post, that is 1970Q1 to 1985Q4 and also 1986 t0 2011 period. They used ADF (Augmented Dickey Fuller) and the Pillips Perron for the unit root and Engel Granger Causality Cointegration in their analysis to investigate the direction causality existing between the openness and the economic growth of two periods. The analysis variable includes: Trade Openness (TO), Government Expenditure (GE) and Investment (I). The cointegration test result displayed a unilateral causality that is existing from economic openness and economic growth in pre-Structural Adjustment Programme (SAP) period; the result shows that openness causes economic growth more in SAP period. The research recommended that the economic policymakers should direct policies towards boarders opening for external trading activities.

Research by Alajekwu, Ezeabasili et al. (2013) was done to establish the relationships between the trade openness, stock markets development and the economic growth of Nigeria between 1986 - 2011. They used Johansen multivariate cointegration and Granger causality test as analysis techniques. The result showed there is statistically not significant and negative relationships between the trade openness and the economic growth in Nigeria. The research recommended the government should develop policies that would create a business environment that is friendly where investors will be financial and legal framework plus trading framework.

Adejoke (2013) investigates the effects of trade openness and the financial investment on the economic in Nigeria for the period between the year 1960 to 2011. It realised that long run statistically significant and positive relationship exists among trade openness, FDI and the economic growth of Nigeria. Emanating from findings of their research, it was recommended that the structural trade-oriented policies be adopted to enhance the economic growth in Nigeria through high flows of export to accumulate more foreign proceed to boost growth in Nigeria.

\section{METHODOLOGY}

To establish a link between variables, this paper used Model of ARDL (Autoregressive Distributed Lag) for its estimates. Before estimation of model, the properties of the variables under study was tested to know levels of stationarity. The type of econometric technique that is used, was ADF (Augmented Dickey-Fuller). For the estimation, our paper also used annual data from 1980 to 2016. Central Bank of Nigeria (CBN Statistical Bulletin was where the data gotten from. This paper adopted a model from the work of Onoh (2013) but with a little modification to estimate relationships among series. Incorporated variables in the model are economic openness (OPEN), real gross domestic product (RGDP), import (IMP) and Export (EXP).
Blue Eyes Intelligence Engineering

\& Sciences Publication 
International Conference on Recents Advancements in Engineering and Technology (ICRAET-18) |15th and 16th March 2019|Siddhartha Institute of Technology \& Sciences, Telangana, India.

Furthermore, after conducting the test of ARDL, this paper conducted test of Granger causality to identify direction and causality nature among the series.

However, this paper used the ARDL approach that was developed by Pesaran et. al (2001) for estimate of the connection between the variable that are under investigation. The main logic behind the choice of this approach are: Firstly, ARDL can be used whether the variables concern are stationary at the level $\mathrm{I}(0)$ or the combination of the both levels. Secondly, it is possible to generate reliable and robust results even if the observations number is large or small. Lastly, it gives an unbiased result of the long run and at the same time valid f-statistics even whether some of its regressors are endogenous (Mika'ilu Abubakar 2014). Aligned with the Pesaran et. al. (2001), the model of ARDL was:

$$
\begin{aligned}
& \Delta R G D P_{t}=\beta_{o}+\sum_{i=1}^{m} \beta_{1} \Delta R G D P_{t-i}+\sum_{i=1}^{m} \beta_{2} \Delta O P E N_{t-i}+\sum_{i=1}^{m} \beta_{3} \Delta I M P_{t-i}+\sum_{i=1}^{m} \beta_{4} \Delta E X P_{t-i}+ \\
& \Delta O P N_{t}=\beta_{o}+\sum_{i=1}^{m} \beta_{1} \Delta O P N_{t-i}+\sum_{i=1}^{m} \beta_{2} \Delta I M P_{t-i}+\sum_{i=1}^{m} \beta_{3} \Delta E X P_{t-i}+\alpha_{1} O P N_{t-1}+\alpha_{2} I M P_{t-1}+\alpha_{3} E X P_{t-1}+\mu_{t}
\end{aligned}
$$

Note that, the $\beta_{0}$ to $\beta_{3}$ and also $\alpha_{1}$ to $\alpha_{3}$ are the explanatory variables parameters. In addition, the ARDL approach of the model of error correction specified as:

$$
\Delta R G D P_{t}=\beta_{0}+\sum_{i=1}^{m} \beta_{1} \Delta R G D P_{t-i}+\sum_{i=1}^{m} \beta_{2} \Delta O P N_{t-i}+\sum_{i=1}^{m} \beta_{3} \Delta I M P_{t-i}+\sum_{i=1}^{m} \beta_{3} \Delta E X P+\beta_{4} E C M_{t-1}+\mu_{t}^{-}
$$

The ARDL model was organised into two parts; the equation first part is with $\beta_{0}$ to $\beta_{3}$ which represent the short run model dynamic while coefficient $\alpha_{1}-\alpha_{3}$ represent long run relationships. Null hypothesis of the above model is defined as $\mathrm{H}_{0}: \alpha_{1}=\alpha_{2}=\alpha_{3}=0$ which inform us that there is no cointegration among the variables under the measurement (Pesaran et. al. 2001). Furthermore, the paper commenced the analysis by the conducting of the test of cointegration of the ARDL so as to know the evidence of long run relationships. Calculated F-Statistics, is being compared with the critical value, as was tabulated by Pesaran et. al. (2001). Whenever the F-Statistics is greater than the upper limit critical value, then the decision rule will be to reject the null hypothesis of no long run relationship, on the other hand when it falls less than a lower critical value, it means the null hypothesis cannot be rejected while when it falls within these two (2) critical bounds, the result is inconclusive (Pesaran et. al. 2001).

\section{RESULTS AND FINDINGS}

In the use of data of time series, it is significant to test the series behaviour nature in other to establish or know the integrations order. To this end, descriptive statistics results as shown in Table 4.1 and conducted test result using the approaches of test of unit root presented in Table 4.2 whereas the approach results of the ARDL Bound testing presented in Table 4.3. Furthermore, the short-run and longrun results were presented in Table 4.4 and 4.5 respectively and also a diagnostic test result presented in Table 4.6. Accordingly, the ADF shows that at first difference, all the variables were stationary.
Table 4.1: Descriptive Statistics Results

\begin{tabular}{llllll}
\hline $\begin{array}{l}\text { Variab } \\
\text { le. }\end{array}$ & $\begin{array}{l}\text { Observati } \\
\text { ons. }\end{array}$ & Mean. & $\begin{array}{l}\text { Std. } \\
\text { Deviati } \\
\text { on. }\end{array}$ & $\begin{array}{l}\text { Minimu } \\
\text { m. }\end{array}$ & $\begin{array}{l}\text { Maxim } \\
\text { um. }\end{array}$ \\
\hline LRGD & 36 & 13.455 & 0.22044 & 13.1830 & 13.8437 \\
P & & 92 & 7 & 6 & 4 \\
LIMP & 36 & 26.935 & 2.66959 & 22.3493 & 30.2466 \\
& & 30 & 2 & 6 & 4 \\
OPEN & 36 & 0.1597 & 0.16951 & 0.00087 & 0.57814 \\
& & 20 & 8 & 9 & 9 \\
LEXP & 36 & 27.312 & 2.64862 & 22.8545 & 30.7588 \\
& & 29 & 3 & 5 & 5 \\
\hline
\end{tabular}

Source: Author's computation.

The data summary used in estimating the between the variables is shown in Table 4.1. The average rates (mean) of the real GDP, import, openness together with the export of the economy, all have positive values. This particular scenario indicates that Nigeria is witnessing an essential improvement in economic growth with import and export having an estimated mean higher than all the other variables during the review period. Import and export have a higher standard deviation, which suggests, that the variability degree of imports and exports are higher than that of any other variable in the distribution. Although, economic openness has a lower standard deviation, which shows that the dispersion of the data is closer to its mean.

Table 4.2: Unit Root Test Results

\begin{tabular}{llll}
\hline Variable. & $\begin{array}{l}\text { ADF at } \\
\text { Level. }\end{array}$ & $\begin{array}{l}\text { ADF at First } \\
\text { Difference }\end{array}$ & Remark. \\
\hline LRGDP & 1.352038 & $-4.838580^{* * *}$ & $\mathrm{I}(1)$. \\
LIMP & -0.817186 & $-5.154805^{* * *}$ & $\mathrm{I}(1)$. \\
LEXP & -0.866484 & $-7.160225^{* * *}$ & $\mathrm{I}(1)$. \\
LOPEN & -1.323268 & $-6.278546^{* * *}$ & $\mathrm{I}(10)$. \\
\hline
\end{tabular}

Source: Author's computation.

According to results presented in table 4.2, at their level values, all the variables are not stationary. Although, they became stationary after taking their first difference. Hence, the conditions for the application of the ARDL (Autoregressive Distributed Lag) bound testing to cointegration is met up, which is the presence of variables both at levels and at their first difference. Although, it is worth noting that the ARDL bound test can only be used in a situation where all variables, are not integrated of order

\begin{tabular}{|c|c|c|}
\hline Estimated Models & $\begin{array}{l}\text { F- } \\
\text { Statistic } \\
\text { S }\end{array}$ & Remark \\
\hline FL $_{\text {RGDP }} /($ LEMPR,LEXR,LFDI,LIM & 5.64892 & Cointegra \\
\hline P,LEXP,LOPEN) & 1 & tion \\
\hline F LIMP $_{\text {(LGRDP,LEMPR,LEXR,LF }}$ & 5.21137 & Cointegra \\
\hline DI,LEXP,LOPEN) & 6 & tion \\
\hline F $_{\text {LEXP }} /($ LGRDP,LEMPR,LEXR,LI & 7.30075 & Cointegra \\
\hline MP,LFDI,LOPEN) & 8 & tion \\
\hline F $_{\text {LOPEN }} /($ LGRDP,LEMPR,LEXR,LF & 6.56293 & Cointegra \\
\hline DI,LEXP,LIMP) & 1 & tion \\
\hline
\end{tabular}
two $I(2)$.

Table 4.3: Results of ARDL Bounds Test 


\begin{tabular}{lll}
\hline Critical Values Bounds & $\begin{array}{l}\text { Lower } \\
\text { Bound }\end{array}$ & $\begin{array}{l}\text { Upper } \\
\text { Bound }\end{array}$ \\
\hline $10 \%$ & 1.99 & 2.94 \\
$5 \%$ & 2.27 & 3.28 \\
$2.5 \%$ & 2.55 & 3.61 \\
$1 \%$ & 2.88 & 3.99 \\
\hline
\end{tabular}

Source: Author's Computation

Table 4.3 is results of ARDL bound test along the critical values bound at the lower part of the table. The results show that all the models have shown the evidence of cointegration among the variables.

Table 4.4: Result of the Estimated Short Run Coefficients of ARDL

\begin{tabular}{lllll}
\hline Variable & $\begin{array}{l}\text { Coefficient } \\
\text { S. }\end{array}$ & $\begin{array}{l}\text { Std. } \\
\text { Error. }\end{array}$ & $\begin{array}{l}\text { T- } \\
\text { Statistics. }\end{array}$ & $\begin{array}{l}\text { P- } \\
\text { Value }\end{array}$ \\
\hline D(LIMP) & 0.158346 & 0.00637 & 24.859353 & 0.0000 \\
& & 0 & & \\
D(LIMP(-1)) & -0.017495 & 0.00727 & -2.405591 & 0.0305 \\
& & 3 & & \\
D(LEXP) & 0.264603 & 0.00744 & 35.550615 & 0.0000 \\
& & 3 & & \\
D(LEXP(-1)) & -0.16295 & 0.00887 & -1.835557 & 0.0878 \\
& & 7 & & \\
D(LEXP(-2)) & 0.000476 & 0.00501 & 0.094828 & 0.9258 \\
D(LOPEN) & -0.422926 & 0.01224 & -34.530701 & 0.0000 \\
& & 8 & & \\
D(LOPEN(- & 0.030316 & 0.01355 & 2.236999 & 0.0421 \\
1)) & & 2 & & \\
D(LOPEN(- & 0.008462 & 0.00500 & 1.690078 & 0.1131 \\
2)) & & 7 & & \\
ECM(-1) & -0.519423 & 0.17422 & -8.721029 & 0.0000 \\
& & 5 & & \\
\hline
\end{tabular}

Source: Author's computation.

Table 4.4 showed results of short run impact of variables on the dependent variables. Coefficients of imports and export had significant and positive impacts on economic growth. A one per cent increase in import and export could led to increase, in $15 \%$ \& $26 \%$ increase in the economic growth respectively although the openness coefficient has a significant and negative impact on the economic growth at one per cent level of significance. The error correction model (ECM (-1)) coefficient revealed a correct sign and statistically significant which measure the speed of adjustment of dependent variables at which the equilibrium is achieved. The result showed that $52 \%$ of any disequilibrium in the economic growth could be adjusted within a lag [a year in the study].

Table 4.5: Estimated Long Run ARDL Coefficients Results

\begin{tabular}{lllll}
\hline Variables. & Coefficients. & $\begin{array}{l}\text { Std. } \\
\text { Error }\end{array}$ & T-Statistics & P-Value \\
\hline LIMP & 0.161215 & 0.007144 & 22.565218 & 0.0000 \\
LEXP & 0.270215 & 0.007142 & 37.831986 & 0.0000 \\
LOPEN & -0.431019 & 0.004040 & -106.677467 & 0.0000 \\
CONSTANT & 0.366414 & 0.103715 & 3.532882 & 0.0033 \\
\hline
\end{tabular}

Source: Author's computation.

The coefficients long-run impacts are showed in Table 4.5. The result showed that the import \& exports, both have a significant and positive impact on the economic growth in long-run at $1 \%$ level of significance. Although, openness has been found to have negatively impacted on the economic growth in the long run.

Table 4.6: Diagnostic Test Results.

\begin{tabular}{lll}
\hline Test. & Test Statistics. & P-Value. \\
\hline Normality & 1.7099 & 0.4253 \\
Serial Correlation. & 0.8841 & 0.7078 \\
Heteroskedasticity & 1.1652 & 0.3914 \\
Functional Form & 1.7795 & 0.0985 \\
\hline
\end{tabular}

Source: Author's computation.

Diagnostic test has been conducted to check the results reliability based on the results on results presented in Table 4.6; the findings are reliable because it has passed all the major tests in the forms of normality, heteroscedasticity, serial correlation and function form.

This paper further conducted stability test to establish the stability or otherwise of the model. The CUSUM (Cumulative sum of recursive residual) and CUSUMQ (cumulative sum of squares of recursive residual) testing approaches were applied, its results were shown in figure 1 \& 2. According to CUSUM and CUSUMQ tests, the estimated model is stable, because the recursive errors fall between two critical lines of the CUSUM and CUSUMQ test respectively.

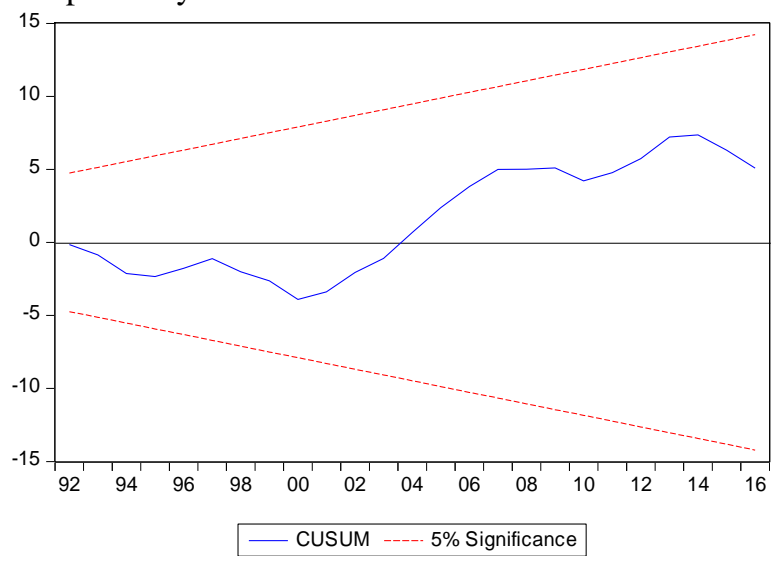

Fig. 1

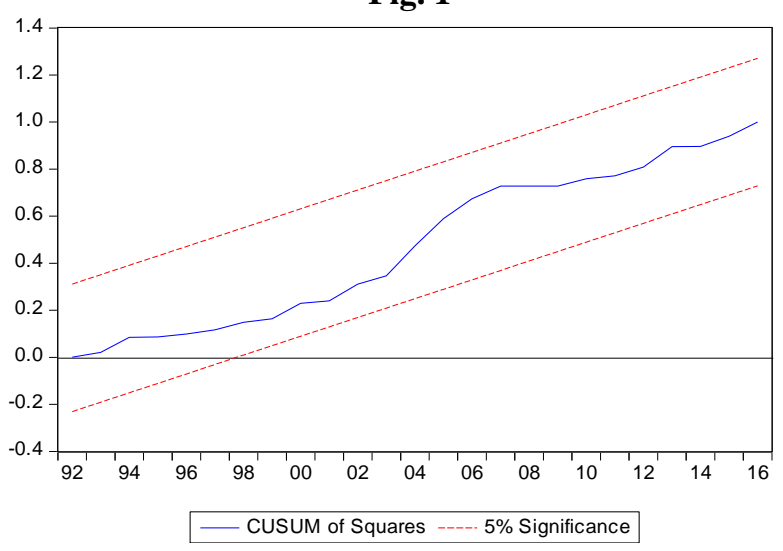

Fig. 2. 


\section{CONCLUSION}

The economy of Nigeria is characterised as an economy that is import dependent. It is imperative to understand the underlying factors that generally determine sources of its economic growth to give room for the policymakers, government authorities and expertise to design and device strong policies that will ensure sustainable economic growth. This is because in the period of economic recession (economic crisis), production and job creation, international trade and investment, price level could be negatively affected. It is in this respect this research, dynamic impacts of trade openness on the economic growth of Nigerian economy was carried out. ARDL results show that economic openness does not cause economic growth throughout the period under study. Although, import and exports cause economic growth during the period of study.

From the above, it has empirically been showned that openness does not cause economic growth of Nigerian economy during review period. Since economic openness had a negative impact on the economic growth, and this is related to fact that our imports are more significant than exports, it hence recommended that there is need for the government to sustain the current efforts of diversifying of the economy to achieve export-led type of economic growth. For example, the agricultural sectors and manufacturing industries should be given priority to produce more in such a way that the country can produce a surplus for exports and not only to produce consumption goods

\section{REFERENCES}

1. Adejoke, S. I. and Olusuyi, E. A., and Babatunde, A. G. (2013). " Trade Openness and Economic Growth in Nigeria: An Empirical Analysis." International Journal of Humaniyies and Social Science Invention 2(6).

2. Pesaran et. al. (2001). "Bound Testing Approach to the Analysis of level relationships." Journal of Applied Econometrics 16(3): 289-326.

3. Alajekwu, U. B., et al. (2013). "Trade openness, stock market development and economic growth of Nigeria: Empirical evidence." 4(3): 120-127.

4. Altee, A. H. and Esmaeel, S.E. and Saled, M. S. (2014). "Financial development, trade Openness and economic growth: Evidence from Sultanate of Oman." Journal of economic and sustainable development 5(23).

5. Asghar, N., et al. (2014). "Financial development, trade openness and economic growth in developing countries: Recent evidence from panel data." 99-126.

6. Bank, W. (2013). Global Economic Perspective: Washington: World Bank.

7. Barro, R. J. Sala.-i.-Martin., X. (2004). Economic Growth 2nd Edition. London: The MIT Press.

8. Barro, R. J. (1991). "Economic growth in a cross section of countries." 106(2): 407-443.

9. Christopher, E. (2014). "Impact of Trade Openness on the Output Growth in the Nigerian." Economy British Journal of Economics, Management \& Trade 4(5): 755 768.

10. Da'Silva, C. (2014). "Impact of Trade Openness on the Output Growth in Nigeria." British Journal of Economics, Management and Trade 4(5): 755-768.

11. Denison, E. F. and Poullier, J.-P. (1967). Why growth rates differ: postwar experience in nine western countries, Brookings Institution Washington, DC. Economic Implications of Remittances and Migration

12. Easterly, W. (1997). "Africa's growth tragedy: policies and ethnic divisions." 112(4): 1203-1250.

13. Edoumiekumo, S. G., et al. (2013). "Economic growth factor in Nigeria: the role of global trade." 1(2): 51-55.

14. Ekpo, A. H. and Egwaikhide, F. O. (1994). "Export and economic growth in Nigeria: A reconsideration of the evidence." 1(1): 100-115.

15. Elenya, K. (2013). "Trade Openness and Economic Growth: A Comparative Analysis of the Pre and Post Structural Adjustment Programme (SAP) in Nigeria." Asian Journal of Business and Economics 3(2).

16. Ezeuchenne, K. (2017). " International Trade and Economic Growth in Nigeria." IOSR Journal of Humanities and Social Science 22(6): 33-43.

17. Ezike, J. E., et al. (2012). "Nigerian foreign trade policy: Its impact on non-oil exports." 4(8): 192-200.

18. Fields, G. S. (1980). Poverty, Inequality, and Development. Nigeria Review of Public Administration and Management. Cambridge: Cambridge University Press.

19. Harris, J. R. and Todaro (1970). "Migration, unemployment and development: a two-sector analysis." 60(1): 126-142.

20. Kingsley, O. K. (2014). "Is trade openness valid for Nigeria's long-run growth? A co-integration Approach? ." Journal of African Institute for Applied Economics.

21. Lewis, W. A. (1954). "Economic development with unlimited supplies of labour." 22(2): 139-191.

22. Mika'ilu Abubakar, B. N. (2014). "Monetary Policy in Nigeria: Any Role for McCallum Rule?" 4(2): 114-123.

23. Myrdal, G. J. (1972). "Asian Drama: An Inquiry into the Poverty of Nations (New York: Twentieth Century Fund, 1968)." 940-941.

24. Nageri, K. I., et al. (2013). "An empirical study of growth through trade: Nigeria evidence." 34(2342): 112.

25. Nduka, K. E. (2013). "Trade openness and economic growth in Nigeria: Journal of Education and Practice." $4(3)$.

26. Nnadozie, E. U. (2013). " Does Trade Causes Growth in Nigeria." Journal of African Financial and Economic Development 3(2).

27. Olaifa, F. G., et al. (2013). "Trade liberalization and economic growth in Nigeria; A Cointegration analysis." 2: 3 .

28. Onoh, O. J. and Ughochukwu, S. U. (2013). "The Impact of Foreign Direct Investment on the Nigerian Economy." European Journal of Business and Management 5(2).

29. Romer, P. (1986). "Increasing Returns and Long-Run Growth." Journal of Political Economy 10: 1002-1037.

30. Saaed, J. A. (2015). "The causal relationship among trade openness, financial development and economic growth: Evidence from Kuwait." Journal of emerging issues in economics, finance and banking (JEIEFB) 1(4): 23063670 .

31. Schultz, T. W. (1980). "The Economics of Being Poor." Journal of Political Economy 8: 639-651.

32. Sinha, D. (2000). "Openness, Investment and Economic Growth Asia." The Indian Economic Journal 49(4): 110117.

33. Solow, R. M. (1956). "A contribution to the theory of economic growth." Quarterly Journal of Economics 70(2): 65-94.

34. Ugbor, I. K. (2014). "Trade Openness and Economic Growth in Nigeria: An Impact." Asian Journal of Business and Economics 3(10): 2241-3602. 
35. Ulasan, B. (2012). Openness to international trade and economic growth: A cross country empirical investigation. Open-assessment e-journal.

36. Wacziarg, R. (2001). "Measuring the dynamic gains from trade." World Bank Economic Review 15(3): 393-429.

37. Yanikayya, H. (2003). "Trade openness and economic growth. A cross country empirical investigation." Journal of Development Economics 72(5): 57-89.

38. Zaren, F. and. Ari, A. (2013). "Trade Openness and Economic Growth: A Panel Causality Test." International Journal of Business and Social Science 4(9): 50-53.

\section{APPENDIX}

A. Descriptive Statistics

\begin{tabular}{|c|c|c|}
\hline & LRG LEM LE & \\
\hline & DP $\quad$ PR 01 & LEXRLFDI LIMP OPEN \\
\hline & 13.452 .08327 .31 & 1.6190 .86526 .930 .159 \\
\hline Mean & $\begin{array}{lll}592 & 038 & 229\end{array}$ & $\begin{array}{llll}938 & 722 & 530 & 720\end{array}$ \\
\hline & 13.351 .74827 .78 & $1.9650 .97426 .02 \quad 0.092$ \\
\hline Mediar & $063 \quad 962 \quad 556$ & $\begin{array}{llll}189 & 033 & 90 & 959\end{array}$ \\
\hline Maxim & 13.847 .76930 .75 & 2.1002 .38230 .240 .578 \\
\hline & $374 \quad 458 \quad 885$ & $\begin{array}{llll}606 & 556 & 664 & 149\end{array}$ \\
\hline Minimu & 13.181 .73522 .85 & $-0.129-0.43022 .340 .000$ \\
\hline$n$ & $\begin{array}{lll}306 & 076 & 455\end{array}$ & $\begin{array}{llll}791 & 252 & 936 & 879\end{array}$ \\
\hline & 0.2201 .3972 .648 & 0.5930 .7092 .6690 .169 \\
\hline Std. Dev & $8477 \quad 204 \quad 623$ & $\begin{array}{llll}347 & 358 & 592 & 518\end{array}$ \\
\hline Skerme: & $80.5933 .880-0.421$ & $1-1.346-0.067-0.4020 .838$ \\
\hline & $\begin{array}{lll}763 \quad 392 \quad 685\end{array}$ & $\begin{array}{llll}096 & 007 & 102 & 389\end{array}$ \\
\hline & & \\
\hline & 412 enم 045 & $\begin{array}{llll}527 & 396 & 276 & 521\end{array}$ \\
\hline
\end{tabular}

Jarque-B 4.405 $346.13 .212 \quad 11.610 .4103 .4264 .455$ $\begin{array}{llllllll}\text { era } & 339 & 18 & 372 & 428 & 393 & 658 & 556\end{array}$ $\begin{array}{lllllllllll}\text { Probabili } & 0.110 & 0.000 & 0.200 & 0.003 & 0.814 & 0.180 & 0.107\end{array}$

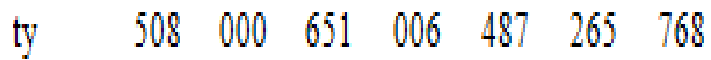

484.474 .98983 .258 .3131 .16969 .65 .749 Sum $\quad \begin{array}{lllllll}133 & 937 & 424 & 778 & 598 & 709 & 925\end{array}$ Sumsq. $1.70068 .32245 .512 .32 \quad 17.61249 .41 .005$ Dev. $\quad 890 \quad 628 \quad 320 \quad 211 \quad 158 \quad 352 \quad 773$

\section{Observat}

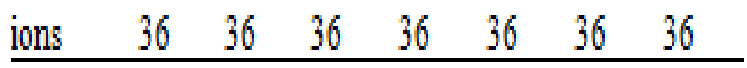

B. Test of Unit Root

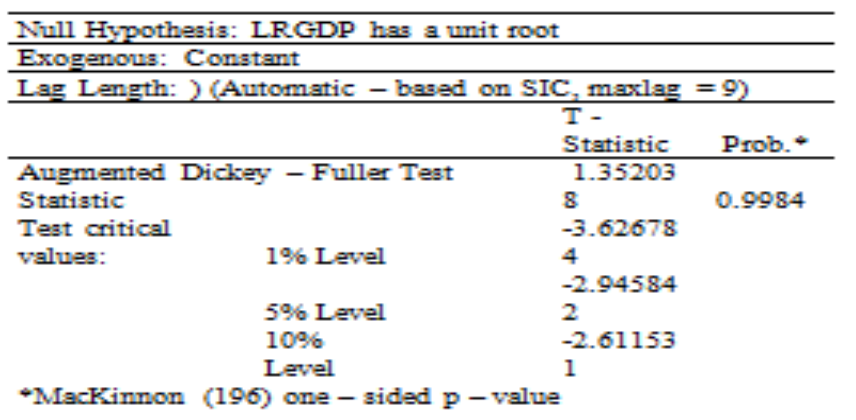

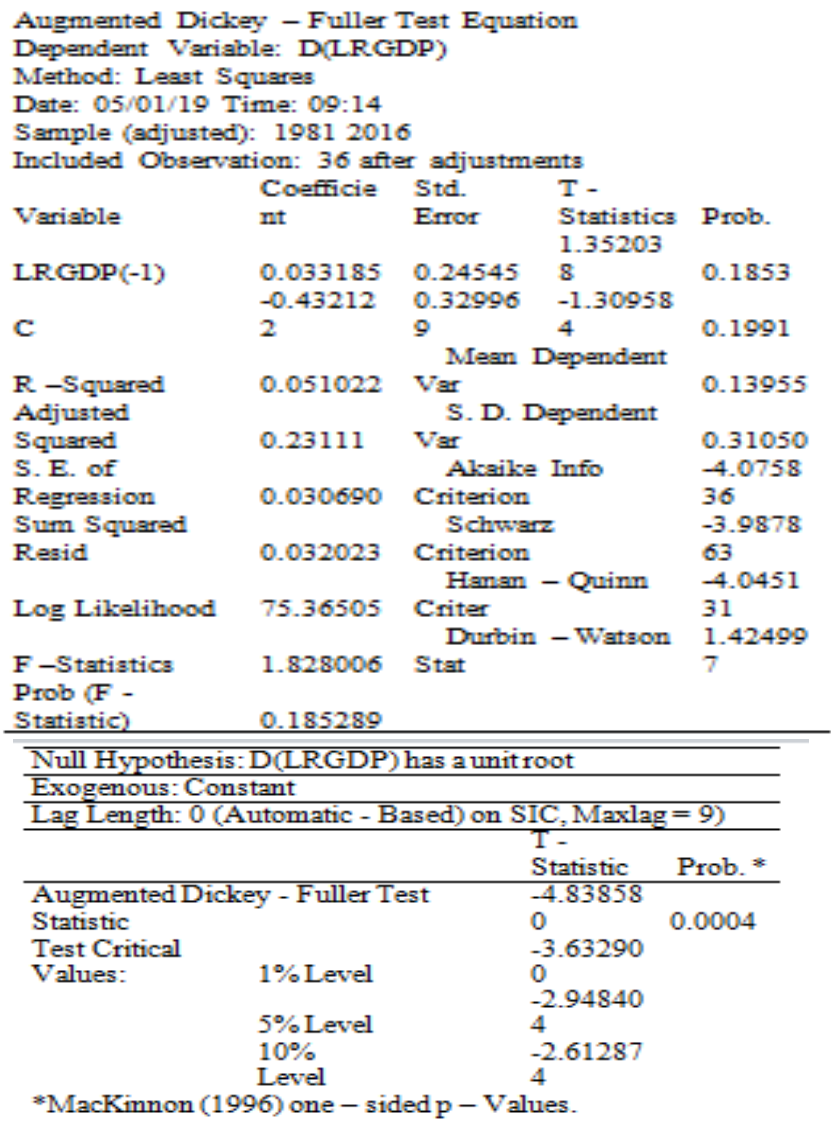

\begin{tabular}{|c|c|c|c|c|}
\hline \multicolumn{5}{|c|}{$\begin{array}{l}\text { Augmented Dickey - Fuller Test Equation } \\
\text { Dependent Variable: D(LRGDP,2) } \\
\text { Method: Least Squares } \\
\text { Date: 05/01/19 Time: 09:15 } \\
\text { Sample (adjusted): } 19822016 \\
\text { Included Observations: } 35 \text { after adjustments }\end{array}$} \\
\hline & Coefficie & & & \\
\hline Variable & $\begin{array}{l}\text { nt } \\
-0.73980\end{array}$ & $\begin{array}{l}\text { Error } \\
0.15289\end{array}$ & $\begin{array}{l}\text { Statistics } \\
-4.82858\end{array}$ & Prob. \\
\hline $\mathrm{D}(\mathrm{LRGDP}(-1))$ & 7 & 8.00521 & 0 & 0.0000 \\
\hline $\mathrm{C}$ & 0.012315 & & 3 & 0.0242 \\
\hline R-squared & 0.415017 & var & & \\
\hline Squared & 0.397290 & var & & \\
\hline $\begin{array}{l}\text { S.E. of } \\
\text { regression }\end{array}$ & 0.02790 & $\begin{array}{r}\text { Akaik } \\
\text { Criterion }\end{array}$ & & \\
\hline $\begin{array}{l}\text { Sum squared } \\
\text { resid }\end{array}$ & 0.25693 & $\begin{array}{l}\text { Schw: } \\
\text { Criterion }\end{array}$ & & $\begin{array}{l}-4.1758 \\
56 \\
-4.2340\end{array}$ \\
\hline Log likelihood & 76.63283 & $\begin{array}{l}\text { Hann: } \\
\text { Durbi }\end{array}$ & $\begin{array}{l}\text { - Quinn } \\
\text { - Watson }\end{array}$ & $\begin{array}{l}53 \\
2.02412\end{array}$ \\
\hline $\begin{array}{l}\text { F-statistic } \\
\text { Prob(F-statistic) }\end{array}$ & $\begin{array}{l}23.41186 \\
0.00030\end{array}$ & Stat & & 8 \\
\hline
\end{tabular}




\section{AUTHORS BIOGRAPHY}

Sunday Elijah is a Lecturer with Federal University Gusau, Zamfara State, Nigeria. He obtained his B.Sc. Economics from University of Maiduguri; Certified Teacher of Teachers Registration Council of Nigeria; Member, Institute of Chartered Economics of Nigeria (ICEN); Member, Nigerian Institute of Management (Chartered); Post Graduate in Education from Usmanu Danfodiyo University, Sokoto; M.Sc. Economics from Bayero University Kano and Currently a Ph.D. Scholar at Department of Economics, Faculty of Economics and Management, Universiti Putra Malaysia.

Ahmed Balarabe Musa, is a Lecturer with Nuhu Bamalli Polytechnic Zaria, Kaduna State, Nigeria. He obtained his B.Sc. and M.Sc. Economics from Bayero University Kano, Nigeria. He is currently a Ph.D. Scholar in the Department of Economics, Faculty of Economics and Management, Universiti Putra Malaysia. 